\title{
Classmaker Trial Towards Studying Result on Social Science Lesson for Elementary School Students
}

\author{
Pranowo N \\ Universitas Veteran Bangun Nusantara \\ Sukoharjo, Indonesia \\ moetis_meida@yahoo.co.id
}

\author{
Toni Harsan \\ Universitas Veteran Bangun Nusantara \\ Sukoharjo, Indonesia \\ toniharsan@yahoo.com
}

\author{
Para Mitta P \\ Universitas Veteran Bangun Nusantara \\ Sukoharjo, Indonesia \\ paramittapurbosari@gmail.com
}

\begin{abstract}
Goverment regulations refer to teachers' professional work in implementing studying evaluation, one of them is teachers' ability in compiling evaluation instrument in class activity. Teachers must always be innovative with technology development appeared that time. One of teachers' responsibilities is doing innovation by using internet facilities, such as classmaker-based online test. By using classmakerbased online test, teachers are assisted in implementing evaluation activity continually in social science lesson. The purpose of this research is doing trial in implementing evaluation of Classmaker-based social science studying for elementary school teachers and students in Subosukawonosraten. Result of this research can be concluded that $\mathrm{t}=3,452 \mathrm{df}=29 \mathrm{M}=0,314 \mathrm{SE}=0,091$. The difference is significant with value $t(d f=29) t=3,452, p=0,002$ is lower or $(p<0,05)$. In other words, there is significant value rise from pretest to posttest on the result of social science studying.
\end{abstract}

Keywords-classmarker, evaluation, social science

\section{INTRODUCTION}

Education development can be reached by increasing studying quality and good evaluation system. Both are connected each other, if education system is good, then the education quality will also be good. Consequently, good evaluation system will support teachers to decide good teaching strategy and motivate students to study in better ways.

Evaluation is a process to gain information about anything which has been studied by students and how successful students has studied it [1]. The result of this studying will be consideration in making decision to make further studying process better. Students studying evaluation is done by teachers to monitor the process, progress, improvement of students studying result based on students' ability. Evaluation can also give feedback for teachers so that they can make perfect plan for studying process. In studying evaluation activity, curriculum does not only ask to use formal test as used recently, but also to use alternative evaluation named portfolio evaluation (authentic) and performance evaluation.

Studying evaluation is an evaluation done inside class or around the environment where studying-teaching process occurs. Activity of studying evaluation includes evaluation done by teachers in delivering lesson material to students. For teachers, studying evaluation is a media which can't be separated from teaching activity, because through evaluation teachers can get information about studying result. Besides, by doing evaluation, teachers can collect information whether the lesson material they deliver can be accepted by students.

Evaluation first appeared in China in 206 BC when Dynasti Han introduced tests to help selection process of the kingdom employees. In 822 AC, Dynasti Tang carried out written test to select kingdom employees, the test lasted for several days and only $2 \%$ who passed it. Successful candidates were then given oral test by the King.

Tests then appeared in Europe, tests were used to to select priests and knights. Students in schools were also tested about cathecism knowledge. Paris University first introduced a test during the 12th century. The test is about theology dispute. In 1974s, Cambridge University started to use oral test to compare college students, this was the same test as held by Dynasti Han in China. During the 18th century, Cambridge University and Oxford University began to test math skill for students by using written test as evaluation for all lesson courses.

The importance of evaluation and the history of evaluation are not separated from the dinamic of society development. Social dinamic always increases, especially in the field technology and information. Recently, technology and information increase very rapidly. For example, some of human works are replaced by machines in form of computers. Computer technology nowadays has entered all life aspects, such as offices, factories, shops, also in education environment .

Even this time computer technology development is sophisticated combining with internet access. According to Ministry of research and technology and higher education of Indonesia, it is recorded that Indonesia is on the sixth biggest place in the world in the number of internet users. In 2014, Indonesian people who access internet at least once a month reaches 83.7 million people. It is estimated that internet users in Indonesia will reach 112 million people before Japan which is in the fifth place in 2017 [11].

Internet-based computer is not only in the form of social media, but also education. One form of technology development in education field is studying evaluation. According to [2]. studying evaluation has following purposes: a) to give clarification about the studying result implemented previously, b) to give information about short term achievement, c) to give suggestion for further progress. 
This research is based on previous research which stated that research development about Classmaker-based studying evaluation has been carried out previously by [3]. entitled "Development of Online Studying Evaluation". The result of the research is that the process of implementation/ coding system of this online studying evaluation system is done by using php programming script with MySQL data base analysis. This implementation/ coding has created a software application program to do online studying evaluation. This evaluation system can handle studying evaluation process of college students in a form of multiple choice, and the result can be directly seen after the test. This online evaluation system has been tested in a small group of college students which consisted of 15 college students from Information Management faculty who are in the third semester. This group has used input device in a form of mouse which is needed to direct choices as chosen. The result of this small group test is that college students tend to choose agree/ strongly agree towards online studying evaluation system (13 out of 15 college students).

Have carried out a research entitled "Development of Web-Based Electronic Module as Physics Studying Media“, [4]. This research is aimed at producing web-based electronic module in a form of mobile version as physics studying media which can be accessed via android smartphone. This mobile version is developed by using blog provider wordpress.com. Based on the evaluation done by lesson material expert and media expert, this is very good to use. Field test is also showed that web-based electronic module in a form of mobile version can improve students' studying achievement which is showed by score of 0.32 .

Has done a research entitled "Evaluation Development and E-Studying - Based Online Assignment With Moodle in Lesson Media of Computer Science Studying“ [5]. The result of this research shows that E-Studying - Based Studying model, which can be accessed on [6]., is based on validation done by expert. The average percentage gained for category software development is as many as $90.42 \%$ and for category educational innovation is as many as $92.22 \%$. For access easiness, as many as $60 \%$ of the users chose 'very good' and as many as $40 \%$ of the users chose 'good'. Appearance aspect gets response as follows: as many as $20 \%$ chose 'very good', $50 \%$ chose 'good', and $30 \%$ of the users chose 'fair'. Navigation aspect gets response as follows: as many as $60 \%$ chose 'good', and for each $20 \%$ of users chose 'fair' and 'not good enough'. For material management aspect, as many as $80 \%$ of users chose 'very good', and as many as $20 \%$ chose 'good'. Self evaluation gets response as follows: as many as $85 \%$ of users chose 'very good', and as many as $15 \%$ chose 'enough'.

Studying evaluation in this research is for Social Science lesson. Social science lesson is an educational program which attempts to develop students' understanding about how human as a single being and social creature can interact with the environment both physically and socially. Social science studying is aimed at developing students' knowledge, attitude, and social skill which are beneficial for students' environment as a part of society [7]. From above explanation, the writer can conclude that Social science studying is an educational program for students to get to know about social world in their environment.

Evaluation on Social science studying should be done continually, intact, and thorough, both for process and result in a form of test and non-test [8]. This definition clearly states that in an evaluation process of social science studying, the evaluation includes both process and result of the students. This evaluation process is done continually and thoroughly. This evaluation will make evaluation process for social science studying become comprehensive.

The above social science studying evaluation uses online system. Online evaluation or online test is a test or evaluation which can be done by students in long distance via internet. Information technology has increased rapidly. Consequently, education field is also improved rapidly for its quality, speed, and easiness, so that conventional test will shift to computerized test, which is online test.

Online test is a method to know students' studying ability, to know students' achievement level, to follow up the assessment result and to give response towards students' studying result quickly and accurately. However, many tests used recently are conventional tests, where students write their answers on the paper provided by teachers. There are many weaknesses in that system, among other are: students can cheat freely, the time to do the test is not fit with the plan, teachers need more time to check students' work, technical mistakes in correcting the work can happen, students tend to be unserious in doing the test, students are bored or afraid, etc. Teachers still correct the students' work manually which need more time. In checking the answers, teachers sometimes make technical mistakes. This is a disadvantage for students, because making mistakes when correcting can give effect to whole students' works.

This research is aimed at doing trial on Classmaker application towards result of social science studying for elementary school students. This is done as an innovation for social science studying evaluation, especially in elementary level. Classmaker application is expected to be able to give quick and accurate evaluation result. This research is a software development with final purpose as software in a form of internet application to support online evaluation which got fund from Ministry of research and technology and higher education of Indonesia in year 2018.

\section{METHODS}

The method used in this research is a development research. The result of a development research is not only to develop an existing product but also to find more knowledge or answer for practical problems. Research method and development are also defined as a research method to create certain product, and test the efficiency of the product [9]. Furthermore, research and development are a strategy or a research method to make practical things better [10].

This development research is done in a form of limited trial in Elementary School of Joyontakan number 14 Surakarta and Elementary School 8 Wonogiri. The control 
group is taken from Elementary School 8 Wonogiri, while the experiment group is taken from Elementary School of Joyontakan no. 14 Surakarta. The technique of data collecting uses the tests of social science studying result implemented in the beginning and the end of social science lesson (pretest and posttest). The technique of data analysis is adjusted with the kind of collected data. That is why, the data gained in this development research is quantitative data in a form of statistic data analysis by using hypothesis test (t-test).

\section{RESULTS AND DISCUSSION}

Statistic analysis is done by using IBM SPSS Statistics 22 for Windows computer program with $95 \%$ level of trust. If the data is normally distributed, it uses paired samples ttest statistics. If the data is not normally distributed, it uses Wilcoxon signedranks test non parametric statistics. The criteria used to draw conclusion is that if sig. (2- tailed)< 0,05 then there is significant difference between pretest and posttest scores; if sig. (2-tailed)> 0,05 then there is no significant difference between pretest and posttest scores.

In other words, there is significantly improving score from pretest to posttest and vice versa. According to Campbell and Stanley [3]. to see whether there is treatment and how much the improvement is, this can be counted using the formula: $(\mathrm{O} 2$ - O1). If the result is negative, the causal effect is negative or there is no effect. On the contrary, if the result is positive, the causal effect is positive or there is effect. The result of score improvement between pretest and posttest will be discussed below.

Table 1. Score Improving Test from Pretest to Posttest on Social Science Studying

\begin{tabular}{ccccccc}
\hline Test Result & T & Df & M & Std.ErrorMean & Sig.(2tailed) & Remark \\
\hline Experiment Group & $\mathbf{3 , 4 5 2}$ & 29 & $\mathbf{0 , 3 1 4}$ & $\mathbf{0 , 0 9 1}$ & $\mathbf{0 , 0 0 2}$ & $\begin{array}{c}\text { There is } \\
\text { difference }\end{array}$ \\
\hline
\end{tabular}

Table 2. Score Improving Test from Pretest to Posttest on Social Science Studying

\begin{tabular}{ccccccc}
\hline Test Result & T & Df & M & Std.ErrorMean Sig.(2-tailed) & Remark \\
\hline $\begin{array}{c}\text { Experiment } \\
\text { Group }\end{array}$ & 3,452 & 29 & 0,314 & 0,091 & 0,002 & $\begin{array}{c}\text { There is } \\
\text { difference }\end{array}$ \\
\hline
\end{tabular}

From the data, it is gained $\mathrm{t}=3,452 \mathrm{df}=29 \mathrm{M}=$ $0,314 \mathrm{SE}=0,091$. This difference is significant with value $\mathrm{t}$ $(d f=29) t=3,452, p=0,002$ is lower or $(p<0,05)$. In other word, there is significantly improving score from pretest to posttest on social science studying result.

\section{CONCLUSION}

From this research, it can be concluded that $\mathrm{t}=$ $3,452 \mathrm{df}=29 \mathrm{M}=0,314 \mathrm{SE}=0,091$. This difference is significant with value $\mathrm{t}(\mathrm{df}=29) t=3,452, p=0,002$ is lower or $(p<0,05)$. In other word, there is significantly improving score from pretest to posttest on social science studying result.

\section{REFERENCES}

[1] Abidin, Y. Desain Sistem Pembelajaran dalam Konteks Kurikulum 2013. Bandung: Refika Aditama, 2014.

[2] Gronlund, N.E dan Linn,R.L. Measurumen and Evaluation in Teacjing 6th. New York:Macmillan Publishing Company, 1990.

[3] Komang Setemen. Pengembangan evaluasi pembelajaran online. Jurnal Pendidikan dan Pengajaran, Jilid 43, Nomor 3, Oktober 2010, hlm.207-214, 2010.

[4] Suyoso dan Sabar N. Pengembangan Modul Elektronik Berbasis Web sebagai Media Pembelajaran Fisika. Jurnal Kepndidikan vol.44 no.1, Mei 2014 hlmn 73-84, 2014.

[5] Bariah, S. H. Pengembangan Evaluasi Dan Penugasan Online Berbasisbe-Learning Dengan Moodle Pada Mata Kuliah Media Pembelajaran Ilmu Komputer. Seminar nasinal Hasil penelitian Universitas Kajuruan, Malang, 2017.

[6] http://estudyingpti.gnomio.com (accesed at 12 Januari 2018).

[7] Saidiharjo. Konsep Dasar Ilmu Pengetahuan Sosial. Yogyakarta: Depdiknas, 2005.

[8] Etin dan Solihatin. Cooperative Learning (Analisis Model Pembelajaran IPS). Jakarta: Grasindo, 2008.

[9] Sugiyono. Metode Penelitian Kuantitatif Kualitatif dan $R \& D$. Bandung: Alfabeta, 2007.

[10] Sukmadinata. Metode Penelitian Pendidikan. Bandung: Remaja Rosdakarya, 2009.

[11] www.kominfo.go.id (accesed at 14 September 2017) 